265. 神経性食欲不振应の食欲不振に ついて

吉利 和, 柴田 長夫

（東大·医・吉利内科）

目的 食欲不振の一環として当科入院の 10 名の神経性 食欲不㗏症について栄養学的な見地から揄討した。

結果 (1)本症患者は病院の給食などは全く無視し, 自 己の好みのものを指図して作らせる。(2)この食事の内容 は総カロリーは少ないが, 食品つ種類は割合に多く, 体重 に比して良質の蛋白浜が多く，時に体重 $1 \mathrm{~kg}$ 当り $2 \mathrm{~g}$ に 達し，かつ動物蛋白も70\%をこえることが多い。1日の 提食量は基礎代謝量程度のことが多いが，時には100〜 $200 \mathrm{Cal}$ 程廖, 多いときは2,000Cal をこえ, 経過中かなり むらがみられる。カロリーが多いときは主食が增すので 動物性蛋白の率は減少する。ビタミン類は少ないことが

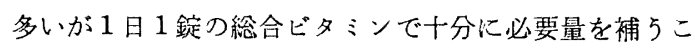
とができるので，軽い久乏症は観察されるが極端な状態 には到らない。(3)本症は心因性, 精神性素因を有するも ので，親，兄弟姉妹との不和その他が唀因となってはい るが，それでもな打親や，祖父母から盲愛され懼れられ て食事に対しては十分わがままのできる者に見られる疾 患で, 低蛋白, 低カロリ一食しか摂れないものでは当然 栄養失調症に移行し死亡してしまうと考えられる。(4)本 症患者には貧血, 低蛋白血症, 下垂体, 甲状腺副腎の軽 い機能低下などの見られるものがあるが，胃下垂の外は 消化機能よく, 肝機能, 堅機能, 血液生化学正常, 感冒 などにも罹患しないのは総カロリーは低いが体重に比し て高蛋白, 高脂肪の良質の食慨を自ら摂っていることに あるのであろう。

266. 病的状態における味覚閾値の変 動一とくに白ネズミ味覚閾值 “Preference Methoł” の検討を 中心として一

佐藤登志郎, 岩見玉子, 馬越 敬子 （德島大·医・栄養）

目的生体が種々の病的状態になると, 嘫好および食 欲に変化の生じることが知られている。しかしその生理 学的な裏づけは, 必ずしも明確ではない。我々は, 個人 ·の嘴好を形づくる感覚器官の一つである味覚の变化と, 嘫好行動の変化との関係をさぐる目的で，この実験をは じめた。
方法および結果 まず味覚閔値の変化を知る一つの方 法として Richter 等によって採用された, Preference Method を用いて, ラットの実験的糖尿病に拈ける，味 覚閾値の変化と併せてこの方法それ自体の検討を行なっ た。

選択閥値として我々は, 総摂取液体に対するテスト溶 液および蒸留水の摂取量を\%で表わし，テスト溶液と蒸 留水との差が $10 \%$ という条件で蒸留水よりるテスト溶液 をたくさんのんだ時の最高濃度の値と定め, 閾値を測定 しその平均を求めた。蔗糖液では正常時よりも糖尿時の 万が,殆んどのラットで閾値の上䄯傾向がみられたが, 統 計的有意差を認めることはできなかった。食塩水でば闘 値の变動は殆んど見られなかった。ラットの個々の搨取 曲線のバラッキが大きいので, 一義的にこの方法で, 閥 値を測定することは困難ざと思う。蔗糖群の体重 $100 \mathrm{~g}$ 当り 48 時間の平均摂取液体量は, 正常時はほほ安定した 一定の摄取傾向を示しているが，糖尿時は，日による差 および個体の掑取量のバラッキが大きい。また正常時よ りる総量で $2 \sim 3$ 倍の液体提取量を示した。正常時は 25 $\%$ の高濃度の庶糖液でも，好んで摂取したが，糖尿時は $7.5 \%$ と $10.0 \%$ との間で, 明らかに㛏悪行動を示した。 これに対して食塩群ではともに, 食塩水 $1 \%$ と $2 \%$ 間 で嫌悪が見られた。糖尿病は食塩に対する喍好をあまり かえないが，蔗糖に対する嗜好を变化させたと思われ る。

以上のことから Preference Method を用いて閔値の 変動を見ることは困難だが，それぞれの摂取曲線からラ ットの㫮好行動を見る上では, この方法は有用なるのだ と思われる。

268. レモンの香りの悪変について （第 II 報）酸性溶液中における シトラールの変性生成物 岩田 伊平, 江沢 郁子, 栗原 長代 （日本女大·食物）

目的 レモンジュースは，貯蔵中に香りが悪変する。 その悪変には、レモンの果皮に含まれている精油の一成 分, シトラールの変性が関与するといわれている。前報 に怙いて，市販シトラールはクェン酸溶液中で变性し， Pーサイメンのほか多くの未確認物質を生成することを 認めた。本実験では, これら未確認物質の5ち 3 種を単 離し, 更に酸性溶液中でのシトラールの变性機䊗につい て2，3の検討を加えた。

方法および結果 市販シトラールをアルコールに溶解 
し, $5 \%$ クエン酸溶液に加え, $38^{\circ} \mathrm{C}$ 恒温器におき, 随時 振望する。4 週間後石油エーテルで抽出し, 水洗, 脱水後 隇王下に溶媒を留去して, シトラールの変性生成物を得 た。变成物を減压 $(6 \mathrm{mmHg})$ 蒸留し, 沸点 $110 \sim 130^{\circ} \mathrm{C}$ (イ)および $130^{\circ} \mathrm{C}$ 以上(口)の留分について，それぞれ徒 酸を用いたカラムクロマトグラフィーを行なった。（イ） を試料としたカラムクロマトグラフィーから得た単離物 （石油エーテルで溶出）は, そのI R, NMR, MS ス ペクトルにより $\mathrm{P}$-メチルイソプロピルペンゼンと確認 した。また（ロ）を試料としたカラムクロマトグラフィ 一からは 2 種類を単離した。両方とも石油エーテルにエ 一テルを $3 \%$ 含む溶㓮で溶出され，それらのI R，NM $\mathrm{R}, \mathrm{MS}$ スペクトルにより，それぞれP-トリイルヂメ チルエチルエーテルおよびPートリイルヂメチルカルビ ノールと認めた。またP-トリイル酸エチルエステルを 用いて合成したPートリイルディチルカルビノールの I Rスペクトルは, 単離物質のそれと一致した。シトラー ルの変性機構検討の結果, 現在まで確認した物質の5 ち，Pートリイルヂメチルカルビノールは，P-メチルイ ソプロピルベンゼン扰よびPートリイルヂメチルエチル エーテルへの移行途上の物質であり, 後者はアルコール の共存により生成されたものと思われる。またPーサイ メンの生成は別の径路をとるすのと思われる。これらの 反応については更に詳細の検討が必要である。

269. 投与油脂がアユの体脂, 香りと 味に及ぼす影響について

竹内 昌昭 (農林省・東海区水研) 吉川 誠次（農林省・食研）

目的 近年, 魚類の盖殖が盛んになってきて, 生産量 は著しく伸びている。これには人工配合飼料の開発，改 良が大きく寄与しているが，従来の人工配合飼料は魚の 成長に重点がおかれていて，生産魚の外観や肉質などそ の品質と与えた飼料との関連については，殆んど明らか にされていない。そこで演者らはアニを供試魚として飼 料に異なる油脂を添加して与えた場合，それが体脂や香 味にどのような影響を与えるかを検討した。

方法 基本飼料（北洋魚粉 73 , 小麦粉 25 , ビタミン混 合 1 およびマッカラム塩 1) にスケソウ肝油分子蒸留残 油，大豆油，ナタネ油およびャシ油をそれぞれ $5 \%$ 添加 した飼料を体重 $6.2 \mathrm{~g}$ のアニに与え飼育し，52 日目と81 日目に取り上げ，脂質分析と配偶法による識別試験を行 なった。81日目には同時期に捕獲された天然ア二につい ても比較した。

結果 フユの脂肪含量は52日目では各飼育群間には差
はなく，81日目になって大豆油添加区，ヤシ油添加区が 他の 2 区に較べてやや低く, 天然魚はさらに少なかっ た。体脂の脂肪酸組成は添加油のそれをよく反映し，特 に脂肪組織において顕著であった。識別試験の結果, 52 日目のアニでは添加油の違いが識別できなかったが，さ らに成長したアユ（81日目）では識別が容易となり，飼 育アニではナタネ油投与アユが最も識別されやすく，天 然アユはさらによく識別された。いずれの場合も味によ るよりも香りによる識別がやや高い正答率を示した。誤 答されやすかったものはスケソウ肝油分子蒸留残油投与 群とヤシ油投与群, 大豆油投与群とヤシ油投与群およで ナタネ油投与群とスケソウ肝油分子蒸留残油投与群など であった。添加油脂の識別試験の結果と魚の識別試験の 結果との間には関連は認められなかった。このことから 撖取された油脂がそのまま蓄積され，アニの香味に影響 するといらょりは二次的に生成されたものが香味を变え るすのと推定される。

270. 牛乳中の酵素と off-flavor の関 係について（第 1 報）

武田 芙美, 金田 尚志（東北大・農）

目的 乳児用の調慗粉乳には，脂肪酸組成を人乳の二 れに近づけるため乳脂の一部を除いたのちリノール酸に 富む植物性油脂が加えられている。この際一部乳脂を除 いた未加熱乳に油脂を添加すると異常臭が発生し，これ はミルク中のリパーゼによるのではないかといわれてい るが詳しい研究は行なわれていない。演者らは，このオ フフレーバーが真にリパーゼのみに上るのかあるいは他 にも原因があるかを明らかにするとともに，ミルクに含 まれる酵素とオフフレーバーの関倸について検討した。

結果 全乳拉よび脱脂乳に油脂を添加した際の臭気の 変化と酸価の経時変化を観察した。その結果, 酸臭, 酸 敗臭,こうじ臭などの発生を認めるとともに酸価も上界 し，これは脱脂乳においてょり著しかった。つぎに，脱 脂乳の $10,000 \mathrm{~g} 60$ 分遠沈物より粗醅索を調整し, 油脂を 添加した殺菌脱脂乳に加えたところ，同様な臭気の発生 と，酸度の上䄯を認めた。そこで，粗醳素中のいかなる 物質がオフフレーバーと関係しているかを知るため, 粗 酵素をセファデックスG-200カラムで6 画分に分画し, それぞれの分画区分を殺菌均質乳に加えてそれぞれの臭 気を官能的に観察するとともに酸度を測定した。その結 果, 各画分ごとに異なった臭気が発生したが酸度の上昇 はfrIIおよび且か著しかった。またこの際発生した臭気 をhead space gasとしてとらえ，ガスクロにより分析し たところ，粗䣼亲および各画分を添加した場合にはカル 
栄 養

ボニル化合物のピークなどは增加したが，官能的に認め られた画分間の臭気の違いはガスクロではとらえられな かった。

271. 豚肝藏の香味成分に関する研究

（第 1 報）呈味成分

松井 年行, 前田 安彦, 高橋 重作

（宇都宮大 $\cdot$ 農 $\cdot$ 農化）

目的 豚肝䁍は栄養価も高く, 風味も良好で高い食品 価仵をすっているが利用面が限られているためか食品化 学的研究対象として取りあげられることは少なかった。 演者らはこの豚肝蔵研究の基磷として風味の解明を試 み, 呈味成分について一応の結果を得た。

結果 豚肝臓が食用に供される時の風味と云うことに 主眼をおき試料は屠殺直後のものでなく新鮮な市販品を 用いた。呈味成分と考え分析を行なったのは遊離アミノ 酸, 核酸関連化合物, ペタイン, クレアチニン, 炭水化 物および有機酸である。遊離アミノ酸は三塩化醋酸除蛋 白エキスを調整し日立アミノ酸自動分析計で定量しグ

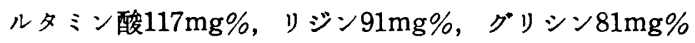
が含有量の多いものであることを知った。アルギニンは 全く含まれなかった。肉に多いアンセリン，カルノシン は肝蔵にはほとんどなかった。核酸関連化合物は陰イオ ン交換カラムクロマト法で定量したがほとんど含有して いなかった。ベタイン，クレアチニンはフリードマン法 を改良した鴻巣法によった。ベタインは意外に多く220 $\mathrm{mg} \%$ 含有し, ベタイン含量の多いと云われている軟体 動物に近い值を示した。クレアチニンは少なかった。以 上の結果でエキス窒素の70\%がその由来を明らかにさ れ，30\%が不明であった。炭水化物はグリコーゲンがき わめて多く $4.23 \%$ 含み，その他低分子糖類としてはグ ルコースが1.14\%で大部分を占め, マルトース, フラク トース, シュークロースを若干見出した。リボースは検 出されなかった。有機酸はクロロホルムーブタノールを 展開荗とするシリカゲルクロマト法を行ない含量の多か った乳酸・コハク酸区分をベンゼンで再クロマトした。 乳酸 $72 \mathrm{mg} \% 、$ コハク酸 $22 \mathrm{mg} \%$ て酪酸, 醀酸が見出され た。この結果豚肝葴の呈味はグルタミン酸, コハク酸の うま味, 乳酸の酸味, およびグルコース,ベタインの甘 味で味が発現し、グリコーゲンによってコク味が加わる と推定される。
272. 加熱による大豆油の呈味性の変 化に関する研究（第 2 報）加熱 油中の遊離脂肪酸およびグリセ ライドポリマー

薄木理一郎, 小林 幸夫, 金田 尚志 （東北大·農・食化）

目的 食用油を加熱した時に生ずる複雑な味の本態を 明らかにせんとし，加熱大豆油を用いて含有成分と呈味 性との関係を追求し，加熱油中の不ヶン化物およびカル ボニル化合物は加熱油の味に影響をすち，なかです炭化 水素の影響がもっとも大きいことを認めたが，これらは 加熱油の味の主体ではないことを既に報告した。今回は 加熱油中の遊離脂肪酸およびグリセライドポリマーと呈 味性との関係について実験した。

方法 加熱油は前報と同じく大豆白絞油を $180^{\circ} \mathrm{C} て ゙ 48$ 時間通気加熱して調整した。(平均分子量 : $\overline{\mathrm{MW}}, 1048$ ) 遊離脂肪酸は加熱油をアルカリ洗いした水層をさらにイ オン交撸樹脂処理して分離しこれを新鮮大豆油に添加 して, 新鮮大豆油との味および臭いの差を官能検査 (二 点識別法およびプロファイル法)により検討した。

結果 両者は $0.1 \%$ の危険率で明膫に識別され，添加 油は味および臭いが共に增加したが，加熱油の強い風味 とはい党ず，加熱油の味の主体ではないと考えられた。 つぎに遊離脂肪酸を除去した中性油を $8 \times 10^{-8} \mathrm{mmHg}$, $160^{\circ} \mathrm{C}$ 扰よび $200^{\circ} \mathrm{C} て ゙$ 子烝留を行なって得たポリマー 区分（MW，2239）の呈味性をみたところ，粘稠性は非 常に高いが，全体の風味は余り強くないことを認めた。 また, ケイ酸カラムクロマトによって得た加熱油のエー

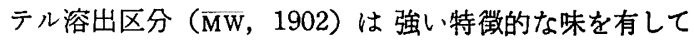
いた。この区分にはグリセライドポリマーおよび極性の 高いグリセライドモノマーが含まれていると思われる が, 前報の結果扰よび分子蒸留, ケイ酸カラムクロマト の結果を併せ考えると，加熱油の味の主体はモノマー以 下の低分子化合物および極性の高いグリセライドモノ、 一であるよ5に思われ，この点についてなお検討中であ る。

273. 压搾パン酵母を原料とする呈味 液の調製について

別所 秀子, 黒沢 祝子, 佐甲 安 (同志社女大·家政・調理科学)

目的酵母は菓分野では単に発泡㓮としてのみなら 
ず香味賦与剤として大きな意味がある。

さきに，われわれは肉を軟化し同時に旨味を䟼与する のには特定のプロテアーゼのみが有効であることを明ら かにし，その使用条件を一応設定した。その後，肉を更 に美味にするため, 手軽くかつ, 安価に入手できるパン 醉母利用について㭲討を行なった。

結果 醉母高源度塩溶液に浸漬するなどの方法で， 醉母細胞内のある種の酵素を亟めて容易に分離すること が知られているが，この方法は酵中の呈味物質の抽出 にも有效で，パン醉母高濃度食塩水に浸漬し，次いで 水で洗浄して塩分を除いた後, エンヂメーション (ENZ YMATION)させ或いはこれに更に市販酵素娮を加えて 消化したところ，確かに美味な呈味液とも称すべきすの が得られた。次いでこのすのの中の旨味物質を検べたと ころ,いろいろのリボヌクレオチドやグルタミン酸その 他種々のアミノ酸などが存在することが判った。

食塩水に浸漬した酵母のンデメーションには $70^{\circ} \mathrm{C}$, 60〜90分間が最適であり，またそのるのの呈味を更に強 化するのには, 酵母のエンヂメーション後, 核酸分解醉 素力の強い市眅醅索剤を加六, $45^{\circ} \mathrm{C}$ 前後に 60〜90 分間 インキュベート（INCUBATE）すると良好で，このよ らにして得られた上澄はいろいろの調理, 特に酢を使用 するそれやシチュー (STEW) などに利用すると料理を

一層美味にするなどのことが判明した。

274. かまぼこの“あし”の諸種判定法 の特性比較

\section{吉岡 黀子（中村学園大）}

国府田佳弘（九大·農・食糧化工）

目的 かまぼこのテクスチャ一の客観的表現は, 志水 らおよび福島によってなされ, 官能検査の結果とも, か なり高い相関があると報告されている。筆者らは，かま にこの“あし”の判定法として, 圧縮および引張り試験 なとの物理的特性を比較しまた，それらと官能検查值 との関連および材料科学的検討を加えたので報告する。

万法試料は,小田原, 仙㱦扣上び博多産の市販かまぼ こ 7 種とした。測定方法は, ダル強度試験機による王縮 試駼, フード・レオメーターによる引張り試験および瓦縮 引張り試験機(テンシロン)による王縮試験を行なった。 併せて, 硬さ, 弾力, 歯切れ怙よび総合評価の食感要素 4 項目について，15名のパネルに官能検査を行ない，評 価の判定法は 7 点法による順位法とした。

結果 ダル強度試験については, 荷重一貫入曲線か ら, 福島の式に準じてY值を算出したところ, 官能検査 との相関はみられなかった。しかし, 立ち上り角度 $\left(\theta_{1}\right)$
と官能検查との相関がみられた。

引張り試験については，志水らのX值を求めたところ 官能検查の硬さおよび弾力とは，相関係数 0.76 お び 0.80 と高い相関がみられた。

テンシロンによる无縮試験に打いては, 貫入量/歪み と官能検查との相関は, 硬さ, 弾力および総合評価が, それぞれ相関係数 $0.69 ， 0.71$ よび 0.70 とかなり高いも のであった。

志水らの式については，材料科学的観点からみると， Nutting-Scott. Blair の式と本質的に同じすのであるこ こからも，X值が，粘弾性状物質の硬さの表現として適 切であると思われた。

275. 人乳複合糖類添加育児粉乳の臨 床実験

吉岡八洲男, 西川 鶖, 金内 稳郎 （雪印研究所）

久原 良躬，高井 俊夫

(阪市大・医・小児科)

目的乳児の腸管内に括ける Bifidus 菌䔄の成因に関 する研究の一環として，大量の人乳から複合糖類を分離 し，これを添加して調慗した育児用粉乳について臨床実 㙠をおこなった。

結果 人乳複合糖類標品はフコースを指標にして調製 したが，人乳には多量の乳糖が含まれており，ゲル沪過 では低分子複合糖類と一部重複するために，本標品はか なり多量の乳糖を含んでいる。本標品のフコースは 6.16 \%で，その35\%が非透析性の高分子形態であり，また， 複合糖類はフコースの 4 倍量とすると約 $24.6 \%$ となる。 試験粉乳は対照粉乳の添加乳糖 (10\%)を人乳複合桾類標 品で代替して調製した。従って, 複合糖類は試験粉乳中 約 $2.46 \%, 15 \%$ 調乳 $100 \mathrm{ml}$ 中約 $0.37 \%$ となる。被検乳児 は生後 $4 \sim 9$ 週の未熟児 5 名で, 試験粉乳で 6 日間哺育 し, その前後の対照粉乳期間を含めた試験期間中の賞便 を採取し、菌漛と糖を測定した。

試験粉乳哺有期間においてては, 対照粉乳哺育期間にく らべて筮便のpHは低下の傾向を示し, Bifidus 菌は実数 値として, あるいは比率として明らかに增加が認められ た。瓷便の糖質は対照粉乳期間においては少量の複合多 糖類のほかにガラクトース,グルコース,フコースが微量 ないし痕跡程度存在するのに対し，試験粉乳期間に批い ては複合糖類がやや多く認められ，その他の糖組成にお いても投与乳の影響が5かがわれた。さらに, 被検乳児 の罴便から分離したBifidus 菌の Biotypeを型別し試験 粉乳による哺育によって, すでに対照粉乳期間に存在す 
る Biotype の增加を認めたが, さらに新らしいBiotype が同時に出現する例も認められた。

以上の結果から, 人乳複合糖類は乳児の腸管内におけ る Bifidus 菌の增殖に対し, 直接的な関連をもつこと ぶ明らかになった。

\section{6. 腎不全の食事療法（第 1 報）}

\section{一人工腎臓例の検討一}

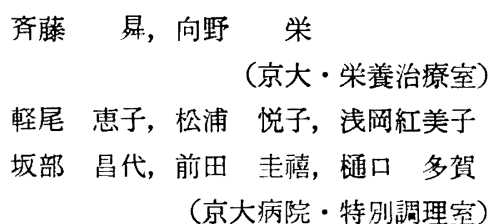

高安 正夫（京大・医・内科）

目的人工腎蔵の血液透析が腹膜灌流や腎移植と共に 慢性腎不全の治療に用いられて来ている。血液透析の 際, 血中に蓄積された代謝産物が除かれると共に, アミ ノ酸の, 透析灌流液への移行子観察されている。キール 型人工腎にて血液透析を受けている腎不全患者 3 例につ いて，食事㞠法の检討を行なった。

結果 第 1 例は 31 才, 男, 身長 $170 \mathrm{~cm}_{\circ} 3$ 年前, PSP 15分13\%で，1,800〜2,000カロリ一, 蛋白 $35 \mathrm{~g}$ により NPNが改善された。昨年再入院，PSP 15分 $0 \%$ NPN 180で腹膜灌流を，次いで血液透析を始めた。透析終了 後より, 次の透析開始迄の期間（約 3 日）について，実 際の食事量を調べ, 熱量, 蛋白質等を計算した。食事蛋 白 $47 \mathrm{~g}$ 以下では, 1 日当り BUN 上年は $12 \mathrm{mg} / \mathrm{dl}$ 以下で あった。蛋白 $45 \mathrm{~g}$ で窒素平衡を思わせたか，183日，50 回の透析て，その間の蛋白 $49 \mathrm{~g}$ ，熱量 1,415 カロリーで は, 貧血は進行していた。腹水もあり, 嗔当な蛋白量は 決め難い。第 2 例は 26 才, 男, 身長 $178 \mathrm{~cm}$ 。PSP15分 1

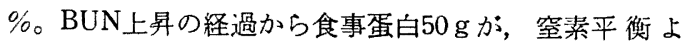
り $47 \mathrm{~g}$ が推定されたが，また158日，39回の透折で, 蛋 白 $55 \mathrm{~g} ， 1,599$ カロリーではへモグロビン等は改善され た。 $55 \mathrm{~g}$ が適当と考えられる $(0.8 \mathrm{~g} / \mathrm{kg})$ 。第 3 の症例 は39才, 男, 身長 $150 \mathrm{~cm}_{\circ} 2$ 年前PSP 15 分 $4 \%$ で, 蛋白 $30 \mathrm{~g}, 1,500$ カロリーでBUNは軽度低下。昨年再入院, PSP $2 \%$ ，蛋白 $37 \mathrm{~g}$ で一時BUNの低下があったが, 再 び上昇し，透析を行な5。蛋白 $37 \mathrm{~g}$ 以下では 1 日当りの BUN 上年は $10 \mathrm{mg} / \mathrm{dl}$ 以下であり, また 94 日, 22 回の 透析で, 蛋白 $34 \mathrm{~g}, 1,107$ カリリの食事でへモグロビ ン等は維持されていた。蛋白 $34 \mathrm{~g}$ が適当である $(0.68$ $\mathrm{g} / \mathrm{kg})$ 。FAO パターンにより食事蛋白の 蛋白価は 68 〜 80 と計算された。熱量は 3 例共 $23 \mathrm{Cal} / \mathrm{kg}$ で低く, 正しい 至適蛋白量を決める場合，十分な熱量が確保されねばな
らない。食事摄取状況では，透析日に熱量，蛋白等はや や低く，2 例では，透析後 $1 \sim 2$ 日で熱量や蛋白等の提 取が最高となり, 他の 1 例では, 透析後 2 日以後に, こ れらの摂取が增した。透析時間は 1 日 8 時間である。

\section{7． 慢性腎不全食による治療効果の} 検討

$$
\begin{aligned}
& \text { 浅野 誠一, 松木 駿, 平田 清文 } \\
& \text { 小沢 幸雄 (慶大・医・内科) }
\end{aligned}
$$

目的 昭和 31 年上り昭和 43 年 4 月まで当大学病院内 科に入院した慢性腎不全患者 180 名の5ち，114名に慢性 腎不全食による食事療法を行なった。99名には慢性腎不 全食一1（たんぱく質 $20 \mathrm{~g} ， 2,000 \mathrm{Cal}$ ), 残りの15名には 慢性腎不全食一2（たんぱく質 $30 \mathrm{~g} ， 2,000 \mathrm{Cal}$ ）が給食 された。以上の患者を調査対象として，慢性腎不全食の 治療効果を下記の 4 項目について検討した。

結果 1) 高窒素血症に対する効果 血清クレアチニ ン濃度を㛑機能（内因性クレフチニン・クリアランス） の指䧣として用いることにより，血液尿索窒素 (BUN) の減少を腎機能と対応して検討した。BUN : 血清クレ アチニン比は, 慢性腎不全食一1では $5: 1$ の周辺にあ り, 慢性腎不全食一 2 で $5: 1$ より7.5：1の間に分 布し，また BUN とクレアチニン分布の上限界は僈性腎 不全食一 1 に扣いて最子高く, 次いてて慢性腎不全食一 2 の順であり，腎而 A 食（たんばく質50 g，1,900Cal）で は遥るかに少る結果であった。

2）血清電解質異常に対する効果 血清ナトリウム, クロール, カリウム, 無機燐等の血清電解質異常の頻度 は食事療法後に改善されたが，血清カルシウムおよび $\mathrm{CO}_{2}$ 抱合能に対しては明らかな効果をみとめなかった。

3）一般栄盖に関する効果として, 治療後の血清たん ぱく, 血色素, コレステロール, 体重等の変化を観察 し, 諸量の娍少傾向をみとめたが, 給食日数と関係なく 栄養上の直接的悪影響はないことが明らかにされた。

4）延命効果を死亡前の患者の血清クレアチニン値と 生存期間との関係より検討した結果, 慢性堅不全食群の 平均血清クレアチニン・レヘルは他の食事群より推計学 的に有意の高値を示し, 後者の死亡前 $1 / 2$ 力月の平均 血清クレフチニン值 $($ 約 $10 \mathrm{mg} / \mathrm{dl})$ は前者の死亡 前 $2 \sim$ 4 カ月と 9 〜2カ月のレベルに相当したことから, 慢性 腎不全食による延命勃果は約 3 カ月〜 1 年間と推定され た。 
278. 慢性腎不全食における特製低蛋 白食品の使用経験
山下 光雄, 松本 敦子, 下瀨川幾世 渡部 昭, 佐伯 達雄, 柴田 真喜 武田 純江（慶応病院・食養課）

目的 慢性腎不全に拈いては，蛋白質が20 g とい5極 度の低蛋白食のために，今まで，献立作成にあたり種々 検討し, 報告して来たか，患者の嗜好，食品の使用方法 等で,かなりの困難があった。今回, 私共岎蛋白含有量 の少ない小麦粉（蛋白含有量 $5.5 \mathrm{~g} / 100 \mathrm{~g}$ 中）を使い, 慢性腎不全食用として，新しく，特製低蛋白パンや特慗 低蛋白スパゲティなどの低蛋白食品の開発を試みた。

結果 特䌘低蛋白パンは, 蛋白含有量が $3.6 \mathrm{~g} / 100 \mathrm{~g}$ 中 と食パンに比べて $1 / 2$ 以下であり, 食味の点においても 劣ることはなく, 患者の好評を得ている。また献立に変化 をつけるためにこのパンに乾ブドウやコュアを入れた ク,バターロール等を作って与えた。短所として, 蛋白含 有量が少ないためか, 乾燥しやすいので, バター, ショ 一トニング等を增量し，ある程度これを防止している。 また特整低蛋白スパゲティは蛋白含有量が $5.6 \mathrm{~g} / 100 \mathrm{~g}$ 中とスパゲティの $1 / 2$ 以下である。このスパゲティは蛋 白含有量が少ないために，多少折れやすく，取扱いに注 意が必要であるが, 茄でる時間は $7 〜 8$ 分と比較的短時 間で阂み，油類を同時に多く使用できることなどの長所 があり利用度は大きい。これらの低蛋白食品を使用する ことにより，(カロリー源としての粉あめの使用量を少 なくするようにした。(2) 4 回食をとり入れて，熱量の配 分と摄取を比較的容易にした。(3)全卵を必ず 1 日25g は 使用するようにして，プロティンスコアを上げることが 出来た。またこの点については，過去十数年間に打ける 食品構成のプロティンスコアを比較すると, 昭和 32 年63 $\%$, 昭和 36 年 $67 \%$, 昭和 39 年 $75 \%$, 昭和 43 年 I 度（蛋白 質 $20 \mathrm{~g}$ 食) $82 \%$ ，II度 $(30 \mathrm{~g}$ 食) $90 \%$ ，となり，スュア が, 順次上䄯し, 最近になって著しく改良されたことが わかった。

279. 患者食における組成変動による 影響 (II)一減程食による治療効 果 $(1)$ -

上月 喆子 (兵庫県立西宮病院)

目的さきに治療の状況を観察, 検討し減脂食の治療 効果に関して第21回総会に打いて報告したが今回はとく に院内基準, 減塩食 $\mathrm{A}$ 食の治療効果について観察した。

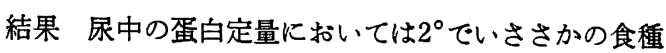
変動による動移を示したが， $3^{\circ}$ に入って下降を辿り治療 食投与終了後す下降を示し正常に復する傾向を示した。 血厈については食種変動による動移が同えないことも ないが一定傾向を知見しえなかった。

残余窒素, 血中蛋白, 血清総コレステロール等も食種 変動による一定傾向を伺 5ことはできなかった。体重は 一县 $1^{\circ}, 2^{\circ}$ 食投与により下降を示しているが $3^{\circ}$ 食に入り 上䄯し経過の良好であることを示した。

以上，一般的傾向としても減塩食に不馿れな処から $1^{\circ}$ 食投与により食欲も減退し， $2^{\circ}$ に移行しても制限食とし ては颜格な状態であるので一般状態は一見不良にみえる が代謝位相は良好な傾向を示しており，3食に入れば経 過如何に拘らず良好で食慨療法の成果を示した。

また，組成分析に関しては三大栄養素を始めアミ， 酸, 徽量成分, ビタミン等に関しても算出, ミネラルに ついて実際に投与した食事の例を分析, 日本化学会, 分析化学会, 家政学会等ですでに方法論, 結果等につい て報告してきたが，再検討し，実施献立の内容と院内基 準拈よび必要量との関連とを併せ検討した。

結果の詳細については紙面の都合て割愛するが,大旨， 基準量を充足して批り, 現行の減塩食 $\mathrm{A}$ 食として比較的 残食す少なく良好であると考えられる。

\section{1. 糖尿教育入院の栄養指導}

\section{西原 豊子（東京都済生会中央病院）}

目的 糖尿病は代謝障害であるので食事療法が大切で ある。当院で 2 週間を単位として教育入院をさせ，昼 食時各自の指示カロリーに合わせた盛付けをさせ，医師 と栄養士で指導を行ない，正しい食事の摂り方の教育を している。

今後の栄養指導の参考とするため, 昭和 43 年, 1 年間 に教育入院をした患者を年令別, 男女別に分け理解度, 実行度を調査し, 退院時のアンケートの結果と併せて検 討した。

結果 1 年間に入院したもの男子 338 名, 女子 126 名, 計464名であった。

退院後初めての来院時, 来院前任意の 3 日間の摄取献 立により調査したもの。

男子251名の調査日数 744 日, 女子 93 名の調査日数 273 日で男女の計344名の調査日数1,017日間である。

調查内容

年令別, 男女別に食品交換表の表 1 から表 6 迄の摂取 状況, 指示カロリーのカロリ一摂取状況, 退院時のアン 
ケート調査である。

摂取状沉はカロリーは，士100カロリー以内のものが $61.9 \%$ ，カロリーが足りないもの $16.6 \%$ ，多すぎたもの $21.6 \%$ であった。

各表毎の年令別, 男女別でみると, 表 1 の主食がわり あいによく，男子が72\%，女子が82\%である。表 2 の果 実, 表 3 の蛋白源, 表 6 の野菜の攝り方が全体によくな く，53\%前後である。表 4 の牛乳はわりあいによく，表 5 の脂肪の摂り方は少し扣ちる。

1 人 3 日間を通して指示カロリー 200 カロリーの簕 囲で守られていたもの男子114名の $45 \%$ ，女子は 65 名の 70\%であった。他は高低がはげしい。

全般的にみて男子より女子の搷り方がよい。年令別で は10才台と60才以上がよくない。年令的に少し無理があ るよ5である。全体的にハラランスのとり方もよくない。

今後指示カロリ一別の摄取状況, 体重の增減の状態の 調査も必要であると思う。

282. 筋萎縮症患児の栄養, 特に鶏卵 添加投与の効果について

\section{木村恒（德島大・医・栄屋）}

目的 昨年の本学会で国立德島療羡所に収容されてい る進行性筋萎縮症患児のクレアチン, クレアチニン代 謝, 血清 C. P.K. の異常並びに全血比重, 血漿比重, 血漿尿素窒素, 血中遊離アミノ酸の5ち特に必須アミノ 酸量が明らかに低值であることを報告したか，今回はこ れら患児の栄養状態，特に蛋白栄養を改善することによ って病状の進行が多少とも阻止できるかどうかを明らか にするために幼年型進行性筋萎縮症患児(平均年令12才) 19 名に 1 人 1 日鵎卵 2 個を間食として70日間投与した場 合における血中遊離了ミノ酸, 窒素代謝, クレアチン, クレアチニン代謝, 一般血液性状その他各種身体機能の 逐日的経過を追及した。

結果 1) 普通食に鷄卵を添加すると筋萎縮症患児の 摄取蛋白の質が動蛋比で47.3\%から60.8\%，E/Tで2.69 から2.80に，蛋白価で93から97に向上し摄取蛋白の量に おいても35\%増加し単位体重当り $2.6 \mathrm{~g}$ になった。この ような食慨を続けて与えたところ血中遊離アミノ酸のう ちクレアチンの合成に関与するアルギニン，グリシン， メチオニンには変化がみられなかったが，その他の必須 アミノ酸量の增加がみとめられた。

2）対照児に較ぺて明らかに少なかった筋萎縮症患児 の窒素蓄積量は摄取蛋白の質量の改善（それによって摄 取熱量す14\%程度增加した）によって窒素蓄積量が明ら
かに多くなった。

3）摂取蛋白の改善によって筋萎縮症状の一指橴とる なされる尿クレアチン排泄量减少し，尿クレアチニン排 泄量の增加傾向がみとめられた。また血清 C.P.K.の著 しい低下を示した。

4）血液性状の5 ち全血比重, 赤血球数, 血漿比重, 血漿尿素窒素並びに肺活量, 握力等の身体的機能にも好 影響がみられた。

283. 循環器疾患発症と栄養に関する 研究一田主丸地区の10年間のフ

$$
\text { オローアップー }
$$

木村 登, 戸嶋 裕德, 水口 宣信 田代 寛美, 美和 芸子, 中山 裕熙

(久留米大・第 3 内科)

目的 昭和 33 年以来循環器疾患の成因ならびに，その 発症に及ぼす諸因子を解明する目的で疫学的研究を行な ってきた。今回は昨年10年目の追求調査を終わった田主 丸地区にて食習慣の変遷と循環器疾患発症との関係を検 討した。

結果 対象は田主丸にて発生し, 該地区を10年以上離 れたことのない40〜64才の男子639名で,これらにつき追 求を行なった。栄養調查は調查時前 24 時間の摄取食飭, 間食, アルコール等卆聴取し, 專任の栄養士が分析し た。これらの結果をもとに, 栄養摄取量の10年間の推移, 体重, 皮厚の增減と栄養扣よび循環器疾患発症との関係 循環器疾患発症者と摄取栄養量との関係, 摂取栄盖量と 血清中性脂肪，血清コレステロールとの関係等をみた。

結論 (1)10年間の栄羡掑取量の推移は総カロリーにて 25\%の減少をみ，また摂取蛋白質に対する動物性蛋白質 の割合は初回 $20 \% ， 10$ 年後37\% と增加しているが，なお 現在，摂取総カロリーの71\%は，糖質で占められてい る。

(2)心筋梗塞の発生は体重減少, 皮厚增加する群に全例 （6 例）の発生をみた。即ち中年以後の肥満，特に皮下 脂肪の增加は心筋梗塞発症に対する 1 つの危険因子と考 えられる。

(3)虚血性心臓病と脳出血, 脳血恮との間には動物性蛋 白の摄取にて有意の差がある。即ち脳出血，脳血栓で 動物性蛋白質の摄取が少なく，総カロリーの大部分が糖 質に由来している。

このことは血清中性脂肪, コレステロールと栄着摂取 量との関係において中性脂肪のみ高い群および血清中性 脂肪, コレステロール共に高い群は正常群に比して有意 に動物性蛋白の摄取が少なく（P<0.001），脳出血，脂 
血栓と同様の傾向にある事より，脳事故発症と摂取栄盖 との関係において興味ある事と考えられる。

\section{4. 胃ガン発ガンに及ぼす食飼の影}

然

$$
\begin{array}{r}
\text { 香川 綾, 香川 芳子, 難波 淳士 } \\
\text { (女子栄養大） }
\end{array}
$$

香川 靖雄（信州大・医）

目的 現今わが国では，ガンが国民死因の第 2 位を占 め,その中でも特に胃ガンが男女ともに $40 \%$ 前後あり,こ れをアメリカ（白人）と比較すると死亡率に扣いて約 6 倍の高率となっている。この原因については, 環境因子 の一つとして日本人特有の食生活が密接に関連すること が疫学的に推論されている。そこで, 杉村等 (1967年) によって N-Methyl-N'-nitro-N-nitrosoguanidine (N G と称す）のガン原性が確認されたのを機会に人の食事 と同じ材料および食品構成からなる日本食と米国食およ
び固型飼料で飼育したラット（各群16匹）に，NGを飲 料水に溶解して投与し人工的に発ガンを試み，飼料によ って胃ガン発ガン状況に差異があるか否かを観察した。 結果 200 日を経過して死亡例が増加しはじめ, 日本 食では242日，米国食では362日にはじめて肉眼的に腫湟 の発生を認め, 400日まで生存したのは日本食群, 固型飼 料群では 4 匹にすぎなかったのに米国食群では 8 匹であ った。自然死を含めてすべてのラットを剖検した結果, 消化管の5ち幽門部から十二指腸および同部の腸間膜付 近に腫瘍が発生して扣り, 病理組織学的検査によれば, 腺胃部に種々の程度に腺組織の異型增殖が認められ，い わゆる腺ガンの発生がみられた。これを飼料别にみる と, N G投与開始後 200 日以降の死亡例および屠殺例に ついて現在までに㭘索の終ったもののうち，日本食では 10 匹中 9 匹，米国食では 9 匹中 3 匹，固型飼料 9 匹中 7 匹に腫瘳が発生しており，米国食群は明らかに低率であ った。

大豆トリプシンインヒヒターとトロンヒンとの相互作用およびプロトロンビンの活性化

大豆トリプシンインヒビター（ＳT I）の阻害特性を 利用してプロトロンビンからトロンビンへの転換の機構 を解明した。動力学的考察から、インヒビターはプロト ロソピンートロソピン転換系のある 1 成分と分子レベル で可逆的反応に関与し, その間にプロトロソビンの転 換率によって決まる結合定数がある。プロトロンビンの 活性化の $2 つ$ つ段階で STI がチモーゲンの転換をブロ ックすることがわかった。第 1 段階は, 当初のペプチド 結合が分解して多形態のプロトロンビン中間生成物とぺ プチド切片を生じる際におこり，第 2 段階は，この中間 生成物がさらに小分子に分割されるときにおこる。この
生成物の 1 つはトロンビン活性を有する。また間接的な 証拋から，トロンビンの蛋白加水分解活性はペプチド結 合の切断によって生じ，この段階で切断されるぺプチド 結合のいくつかは S T I の反応部位と結合するものと同 じである。ヒトやウシのトロンビンはＳT I 1 モルと結 合し解離可能な酵素一インヒビター複合体を形成する。

Interaction of Soybean Trypsin Inhibitor with Thrombin and Its Effect on Prothrombin Activation.

by Lanchantin, G. F., et al; J. Biol Chem., 244(4), 865 875 (1969).

(堀井) 